papers in the Transactions and Praceedings of the Chemical Society, mostly in his name alone, shows a fine, comprehensive record of systematic and accurate work on an important branch of organic chemistrya branch now becoming increasingly important in connexion with the chemistry of plastics and drugs.

On a few occasions, Dixon, to confirm certain theories of his, had recourse to physico-chemical mothods. He was an expert at mechanical operations and a first-rate glass manipulator. Further, he collaborated with Prof. Hartog on the chemical aspect of certain biological problems. In these activities also he was a master of his subject. Apart from his research ability, he was an excellent and stimulating lecturer; he followed the Hofmann tradition of showing many elaborate experiments in his undergraduate classes. He also took a keen interest in the erection of new chemical laboratories in University College, Cork, and was responsible for many novel ideas in their design and equipment.

Prof. Dixon was of a retiring disposition, and only his intimate friends were aware of his very active scientific life. $\mathrm{He}$ served for five years on the Council of the Chemical Society, London. He was also a member of a special research committee of the Royal Society. His hobby was photography, in which he was an expert, and he was one of the founders of the Cork Photographic Society. He was president of the Society until his departure to Sidcup, Kent, on retirement in 1924.

Dixon married Miss Nina Haughton, of Dublin, in 1888, and his two sons graduated at University College, Cork : Wilfred (who died soon after graduation) in medicine, and Emerson in engineering. He is survived by his widow, one son and a married daughter.

JosePH REILLY.

\section{Dr. J. D. Rolleston}

BY the death on March 13, at the age of seventythree, of Dr. J. D. Rolleston, British medicine has lost a man who had an international reputation for his work on the clinical aspects of the infectious diseases, and in the field of the history of medicine. His friends had for some time noticed a gradual decline in his physical powers, and his death took place as the termination of a short illness.

John Davy Rolleston was the son of Dr. George Rolleston, Linacre professor of anatomy and physiology at Oxford. There 'J. D.' was born in 1873, and he was thus junior by eleven years to his brother Humphry, later destined to become the regius professor of physic at Cambridge, and president of the Royal College of Physicians. J. D. Rolleston was a classical scholar both of Marlborough and of Brazenose College, Oxford. His medical training was obtained at Charing Cross Hospital between 1895 and his qualification in 1900 . He graduated M.D. (Oxon.) in 1904.

Rolleston spent practically the whole of his professional life as a specialist in the acute infectious diseases. Between 1902 and 1930 he served in three of the hospitals of the Metropolitan Asylums Board. Possibly his most intensive period of literary activity in the clinical field was reached while he was senior assistant medical officer of the Grove Fever Hospital. In 1926 he became medical superintendent of the Western Fever Hospital at Fulham, and he retained this position after the M.A.B. hospitals were transferred to the London County Council, and until his retirement in 1938. He was an able hospital administrator and a clinician of great skill, whose interests and knowledge extended widely beyond the domain of the specific fevers.

It was in the field of medical literature that Rolleston's name became widely known in many countries. In 1925 he produced his exhaustive textbook on the "Acute Infectious Diseases", and other editions followed in 1929 and in 1940. At the time of his death he was working on a fourth edition. This book summarized the literature as few similar books have ever done, and the first-hand nature of most of the book is indicated by the fact that he quotes nearly ninety papers by himself alone on the various diseases. In the clinical field Rolleston also contributed freely to various abstracting journals, to the Medical Annual, and to the British Encyclo. poedia of Medical Practice; and he edited the British Journal of Children's Diseases during 1910-44.

Dr. Rolleston was also well known for his writings on the history of medicine. He was president of the Section of the History of Medicine of the Royal Society of Medicine, and in 1935-36 he delivered the Fitzpatrick Lectures before the Royal College of Physicians. These lectures were eventually published as "The History of the Acute Exanthemata". $\mathrm{He}$ was an honorary member of the Royal Rumanian Society for the History of Medicine and a member of the Société Française de l'Histoire de la Médecine. In 1922 he was general secretary of the International Congress of the History of Medicine which was held in London, and in 1925 he was vice-president of honour of the Geneva Congress. He was interested in several languages, and in French literature he was especially proficient. He was a life-long student of Voltaire, and he had published papers on the French philosopher.

Dr. Rolleston was a member of the council of the Society for the Study of Inebriety, and he did much important work in this field. During his later years he devoted a great deal of attention to the relations between folk-lore and medicine, and he was also a member of council of the Folk-lore Society. He had for long been a corresponding member of the Société de Pédiatrie de Paris. $\mathrm{He}$ had for many years been associated with the Royal Society of Medicine, and at one time or another he was president of four sections-history, children, epidemiology and State medicine and clinicalwhich possibly constitutes a record. After his retirement in 1938 he contributed to the journals no fewer than twenty articles on folk-lore and literary subjects. He had served as honorary librarian of the Royal Society of Medicine, and as representa. tive of the Royal College of Physicians on the committee of management of the Chelsea Physic Garden.

Dr. Rolleston is survived by his widow, a son and a daughter.

E. AsHWORTH UNDERWOOD.

DR. W. J. C. ORR, who died on March 13, held an I.C.I. Fellowship in Chemistry at the University of Glasgow, having taken up this post in October last year. Previously he had held a research post with the British Rubber Research Association, and had worked in the Universities of Cambridge and Edin. burgh. He was well known for his work in physical chemistry, especially on reactions involving isotopes, thermodynamics generally, and bond energies, on which subjects he had published a large number of papers. 